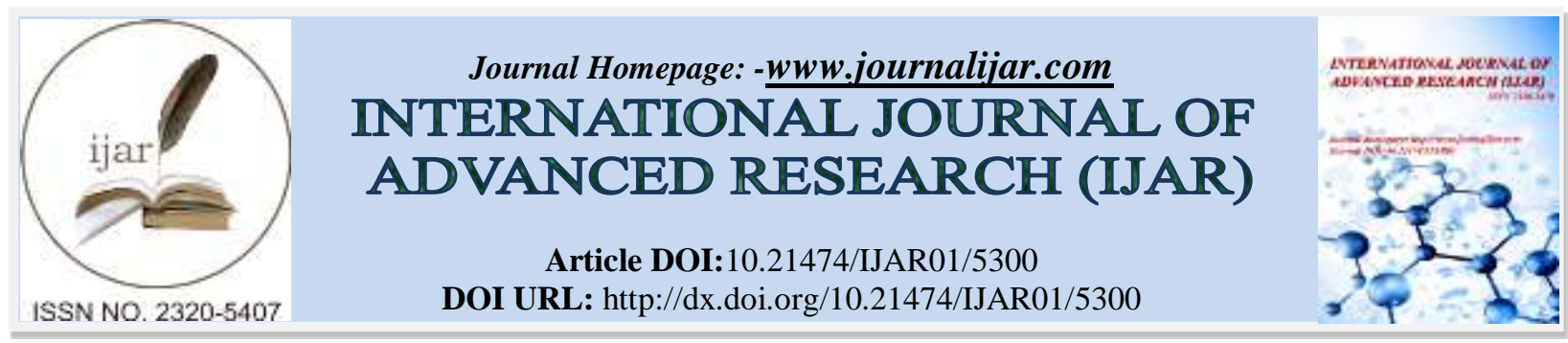

RESEARCH ARTICLE

\title{
STUDENTS' METAPHORICAL PERCEPTIONS RELATED TO REWARD AND PUNISHMENT IN EDUCATION.
}

Hülya Pehlivan and Pınar Köseoğlu.

\section{Manuscript Info}

.1........................

Manuscript History

Received: 01 July 2017

Final Accepted: 03 August 2017

Published: September 2017

Key words:-

Reward-punishment, metaphor, metaphoric perception.

\section{Abstract}

This study aims at exhibiting prospective biology teachers' perspectives of reward and punishment in education. The study group was composed of 99 pre-service biology teachers attending the Biology Education Department of Hacettepe University in the 2015-2016 academic year. The participants were given a semi-structured questionnaire form containing the statements "reward/punishment in education is just like... because....", and "a teacher giving reward/punishment in education is just like.... because...." The participants were also asked to answer the question "what three things does reward/punishment in education remind you of?" The technique of content analysis was employed in this study in analysing the data obtained. The data were analysed through MAXQDA12 - a program for qualitative data analysis - and then were interpreted. Accordingly, students perceive reward in education as a positive element whereas they perceive punishment as a negative element.

Copy Right, IJAR, 2017,. All rights reserved.

\section{Introduction:-}

Reward and punishment in education is an issue in need of further research. One of the most important issues in education is, undoubtedly, discipline and reward/punishment used to establish discipline (Calik, 2016). Both methods provide teachers with a lever in education, and they can lead to positive or negative results. Teachers employ methods of psychological or social reward and punishment in classroom management (Yilmaz\&Babadogan, 2013). Studies have shown in general that reward has positive effects on students (Navaro, 2009; Nuttin\& Greenwald, 2014; Yaman\&Guven, 2014) whereas punishment has negative effects (Dokmen, 2005; Nuttin\& Greenwald, 2014; Swanson, 2001; Yaman\&Guven, 2014). Punishment is not influential in changing behaviors in the long term (Aydin, 2006). As Hoffman, Hutchinson and Reiss (2009) also point out, educational systems use reward and punishment in conducting effective educational activities and in establishing discipline for the purposes of controlling students' behaviors; and the feelings, thoughts and behaviors of students who are exposed to reward and punishment are shaped accordingly.

Reward and punishment should be purposeful, they should not be given without a reason, and students should be informed of any potential consequences beforehand. Students who are not informed in advance do not take on responsibility, and make accusations towards their teachers (Romi\&Roache, 2012). It is obligatory that any reward or punishment be purposeful, meaningful, proportional to behaviors, and appropriate to students' development to obtain effective results in the use of these strategies (Aydin, 2000). The practice of rewarding and punishment which is not proportional to behaviors and which is not announced beforehand can yield negative results. Punishment given in aggressive and hostile manners leads to negative results and causes deterioration in students' behavior. A 
combination of rewards and punishments directing students towards correct behaviors, on the other hand, will encourage students to take on responsibility and will reduce their incorrect behaviors. The "carrot and stick approach" is a term referring to offering a combination of reward and punishment in order to stimulate good behavior (Roache\& Lewis, 2011).

Using metaphor to understand students' approaches to reward and punishment can offer important benefits. A metaphor is a way of understanding or experiencing a phenomenon according to another phenomenon (Lakoff\& Johnson, 2005). Thus, metaphors enable us to understand complex and difficult issues and to interpret them (Moser, 2000). They are effective instruments in describing a complex and abstract issue (Wahyudi, 2007). They are also instruments enabling us to map an experience and to understand complex subjects and new situations (Vosniadou, 1989). The most important tool improving problem solving and creative thinking skills is the use of metaphors (Arslan\&Bayrakci, 2006). Use of metaphors can be explained with a system involving linguistic, semantic, and cognitive dimensions (Charteris-Black, 2004).

Metaphors are very strong instruments for learning and teaching (Vadeboncoeur\& Torres, 2003). They develop and increase students' thinking skills and creativity, and they also increase students' participation. Metaphors are used in many fields in educational research in order to determine students' and teachers' perceptions in other words (Aydin and Pehlivan, 2010).

Several studies analyzing metaphorical perceptions (Abril\& Bannerman, 2015; Alger, 2006; Arik\&Ozdemir, 2015; Aslan, 2016; Ekiz\&Kocyigit, 2013; Eren, Celik\&Akturk, 2014; Gamlem\& Smith, 2013; Ibret\&Aydingozu, 2011; Kaya, 2014; Koc, 2013; Leavy, Mcsorley\&Bote, 2007; Martinez, Sauleda\& Huber, 2001; Nikitina\&Furuoka, 2011; Tannehill\&MacPhail, 2014) are available in the literature. However, the number of studies analyzing perceptions of reward and punishment on the basis of metaphors is very small. Turhan\&Yaras (2013), for instance, describe students' and teachers' thoughts about the concepts of discipline, school director, classroom rules, and reward and punishment through metaphors.

\section{Purpose of the Research:-}

This study aims to demonstrate prospective biology teachers' perceptions in relation to "reward and punishment in education" and "teachers giving rewards and punishment in education" through metaphors.

\section{Research Problem:-}

1. In what metaphors do prospective biology teachers describe their perceptions of "reward and punishment in education" and of "teachers giving rewards and punishment in education"?

2. Into what conceptual categories are prospective biology teachers' metaphors about their perceptions of "reward and punishment in education" and of "teachers giving rewards and punishment in education" divided according to their similarities?

\section{Method:-}

\section{Research Design:-}

This study uses the design of phenomenology - one of qualitative research methods. Because phenomenology is used to focus on phenomena of which we are aware but do not have in-depth and detailed understanding (Gocer, 2013), this method has been selected.

\section{Study Group:-}

The study group was composed of 99 pre-service biology teachers attending the Biology Education Department of Hacettepe University in the 2015-2016 academic year.

\section{Data Collection:-}

The participants were given a form containing the statements "Reward/punishment in education is like.... because....", "Teachers giving rewards/punishment are like... because....", and "Three things reward/punishment in education brings into mind" within the scope of the research, and they were asked to complete the semi-structured form. No comments were made about the content during the applications so as to prevent misleading in relation to the concepts. 


\section{Data Analysis and Interpretation:-}

This study analyzes the metaphors developed by prospective teachers through content analysis. Deductive method is used in content analysis and primarily relevant categories are distinguished (Ozdemir, 2010). A five-stage process of evaluation which was used by other researchers (Ates\&Karatepe, 2013; Aydin\&Unaldi, 2010; Saban, 2008) was used in the content analysis. The stages undertaken were as follows: (1) coding/eliminating; (2) classifying; (3) categorizing; (4) validity and reliability study: the data obtained, how the data were reached, and the results obtained from the data were described clearly in this study, and the metaphors categorized were revised again by consulting expert opinion at the stage of reliability attainment. The results obtained with the help of experts was calculated with the formula "Reliability $=$ agreement/agreement + disagreement X100". Consequently, agreement between the researcher and the expert was found to be $91 \%$. In cases where agreement between researchers and experts is $90 \%$ or above, reliability is considered to be adequate (Saban, 2008; Saban, 2009; Saban, Kocbeker\&Saban, 2006); (5) putting the results into the computer and calculating the number of metaphors as well as the frequencies (f) and percentages (\%). The data were coded using MAXQDA 12.

\section{Findings:-}

99 university students included in the research created metaphors about "reward and punishment in education" and about "teachers giving rewards and punishment in education" via six semi-structured questions. They were also asked to specify three things reward/punishment brings into their mind. Conceptual categories were formed with the metaphors created, and they were tabulated. Then the data in the tables were analyzed and interpreted.

Table 1:- Findings about the statement "Reward in education is like.... because...."

\begin{tabular}{|l|l|c|c|l|}
\hline Categories & $\begin{array}{l}\text { Reward in education is like.... } \\
\text { because.... }\end{array}$ & $\begin{array}{l}\text { Number of } \\
\text { metaphors }\end{array}$ & Frequencies & Percentages \\
\hline $\begin{array}{l}\text { Reward as an } \\
\text { encouraging/illuminating } \\
\text { element }\end{array}$ & $\begin{array}{l}\text { Reinforcement (17), Food (17), Gift } \\
\text { (6), Achievement (4), Motivating } \\
\text { (4), Happiness (4), Cure (3), Habit } \\
\text { (2), Courage (2), Feedback (2), } \\
\text { Necessary (2), Money (2), Sport } \\
\text { (2), Supportive (2). }\end{array}$ & 14 & 69 & $\mathbf{8 8 . 5}$ \\
\hline $\begin{array}{l}\text { Reward as a negative } \\
\text { element }\end{array}$ & $\begin{array}{l}\text { Punishment (2), Blind alley at two } \\
\text { ends (1), Bribe (1), Cigarette (1). }\end{array}$ & 4 & 5 & $\mathbf{6 . 4}$ \\
\hline No answers & No answers (4). & & 4 & $\mathbf{5 . 1}$ \\
\hline TOTAL & & $\mathbf{1 8}$ & $\mathbf{7 8}$ & $\mathbf{1 0 0}$ \\
\hline
\end{tabular}

Reward as an encouraging-illuminating element: Some of the statements in this category are shown in the following:-

"Reward in education is like reinforcement because it increases the desire to learn."

"Reward in education is like food because it makes an individual happy."

"Reward in education is like a gift because it increases motivation."

Reward as a negative element:-

Some of the statements in this category are shown in the following:

"Reward in education is like punishment because it causes addiction."

"Reward in education is like a cigarette because it becomes a habit by arousing desire to succeed."

Table 2:-Findings about the statement "Teachers giving rewards in education are like.... because...."

\begin{tabular}{|c|c|c|c|c|}
\hline Categories & $\begin{array}{r}\text { Teachers giving rewards in education } \\
\text { are like.... because.... }\end{array}$ & $\begin{array}{r}\text { Number } \\
\text { of } \\
\text { metaphors }\end{array}$ & Frequencies & Percentages \\
\hline $\begin{array}{r}\text { Teachers as an } \\
\text { encouraging/illuminating } \\
\text { element }\end{array}$ & $\begin{array}{r}\text { Conscious (4), Successful (4), Creative } \\
\text { (3), Educated (2), Encouraging (2), } \\
\text { Guide (2), The Sun (1). }\end{array}$ & 7 & 18 & 24 \\
\hline Teachers as a need & $\begin{array}{l}\text { Food (12), Family (9), Friend (3), Water } \\
\text { (2), Tree (2). }\end{array}$ & 5 & 28 & 37 \\
\hline Teachers as the owners & Justice (2), Ambitious (2), Employer (2), & 6 & 10 & 13 \\
\hline
\end{tabular}




\begin{tabular}{|r|r|r|r|r|}
\hline $\begin{array}{r}\text { of power and as the } \\
\text { leaders }\end{array}$ & $\begin{array}{r}\text { King/Queen (2), Bank (1), Power (1), } \\
\text { Referee (1), Authority (1), Hero (1). }\end{array}$ & & \\
\hline $\begin{array}{r}\text { Teachers as an } \\
\text { emotional expression }\end{array}$ & $\begin{array}{r}\text { Angel (5), The best teacher (3), } \\
\text { Affectionate (2), Beloved (1). }\end{array}$ & 4 & $\mathbf{1 5}$ \\
\hline $\begin{array}{r}\text { Unsuccessful (1), Ignorant (1), } \\
\text { element }\end{array}$ & $\begin{array}{r}\text { Inexperienced (1), Apple polisher (1). } \\
\text { No answers }\end{array}$ & No answers (4). & & 4 \\
\hline TOTAL & & $\mathbf{2 6}$ & $\mathbf{5}$ \\
\hline
\end{tabular}

Some of the statements in this category are shown in the following:

\section{Teachers as an encouraging-illuminating element:-}

Metaphors in this category are prominent from the aspect of being encouraging and illuminating. Some of the statements in this category are shown in the following:

"Teachers giving rewards in education are like someone who is conscious because they try to encourage students."

"Teachers giving rewards in education are like the sun because they always shine and they both heat and illuminate us."

"Teachers giving rewards in education are like a guide because they aim to show students positive behaviors."

\section{Teachers as a need:-}

This category is mostly composed of students' statements perceiving teachers giving rewards in education as an entity that we need. Some of the statements in this category are shown in the following:

"Teachers giving rewards in education are like food because they motivate students into the lesson and they make students love them."

"Teachers giving rewards in education are like a family because they feel happy and they make students happy when they have achievement in return for their efforts."

"Teachers giving rewards in education are like water because students need such teachers."

Teachers as the owners of power and as the leaders:-

It may be said that students' statements in this category consider teachers giving rewards in education as people holding the power and as the authority. Some of the statements in this category are shown in the following:

"Teachers giving rewards in education are like justice because they give what is needed in return for achievement."

"Teachers giving rewards in education are like referees because they are liked by supporters if they decide on a penalty."

"Teachers giving rewards in education are like heroes because it is important to respond to people's efforts."

\section{Teachers as an emotional expression:-}

This category contains students' statements which consider teachers giving rewards in education as an emotional expression. Some of the statements in this category are shown in the following:

"Teachers giving rewards in education are like angels because they provide students with an angel's wing by giving a reward.”

"Teachers giving rewards in education are like someone affectionate because they assure that achievement is long-lasting/permanent."

"Teachers giving rewards in education are like the beloved because you love more once you love them."

\section{Teachers as a negative element:-}

The metaphors in this category indicate that students perceive teachers giving rewards in education as negative. Some of the statements in this category are shown in the following: 
"Teachers giving rewards in education are like unsuccessful individuals because students do not want to study harder unless they are given a reward."

"Teachers giving rewards in education are like inexperienced people because they have not faced the impacts caused by a reward before."

"Teachers giving rewards in education are like someone ignorant because they do not know how to make students dependent on them."

Table 3:-Findings about the statement "Three things reward in education brings into mind"

\begin{tabular}{|c|c|c|c|c|}
\hline Categories & Three things & $\begin{array}{l}\text { Number } \\
\text { of } \\
\text { metaphors }\end{array}$ & Frequencies & Percentages \\
\hline $\begin{array}{l}\text { Reward as an } \\
\text { encouraging/illuminating } \\
\text { element }\end{array}$ & $\begin{array}{l}\text { Words of appreciation (38), Food (30), } \\
\text { High marks (26), Achievement (24), } \\
\text { Motivation (12), Gift (8), Encouragement } \\
\text { (8), Books (6), Positive behaviors (6), } \\
\text { Pencil (6), Competition (3), Behavior (3), } \\
\text { Interest (3), Homework (3), Gain (6), } \\
\text { Having benefits (2), Supporting (2), } \\
\text { Classical conditioning (2), Pavlov's dog } \\
\text { (2). }\end{array}$ & 19 & 190 & 71 \\
\hline $\begin{array}{l}\text { Reward as an emotional } \\
\text { expression }\end{array}$ & $\begin{array}{l}\text { Happiness (23), Ambition (8), Joy (6), } \\
\text { Desire (6), Trust (4), Excitement (4), } \\
\text { Flower (2), Entertaining (2), Peace (2), } \\
\text { Passion (2), Surprise (2), Enjoying going } \\
\text { to school (2). }\end{array}$ & 12 & 63 & 24 \\
\hline $\begin{array}{l}\text { Reward as a negative } \\
\text { element }\end{array}$ & $\begin{array}{l}\text { Choosing the easy way (2), Decrease in } \\
\text { success (1), Disappointment (1). }\end{array}$ & 3 & 4 & 2 \\
\hline No answers & No answers $(9)$ & & 9 & 3.4 \\
\hline Total & & 34 & 266 & 100 \\
\hline
\end{tabular}

Table 4:-Findings about the statement "Punishment in education is like.... because...."

\begin{tabular}{|c|c|c|c|c|}
\hline Categories & Punishment in education is like.... because.... & $\begin{array}{l}\text { Number } \\
\text { of } \\
\text { metaphors }\end{array}$ & Frequencies & Percentages \\
\hline $\begin{array}{l}\text { Punishment as a } \\
\text { negative element }\end{array}$ & $\begin{array}{l}\text { Bad behavior (17), Bad (6), Negative } \\
\text { reinforcement (4), Having a vaccination (4), } \\
\text { Crime (3), Undesired dish (3), Bitter food (3), } \\
\text { Prison (2), Wall (2), Mistake (2), Diet (1), } \\
\text { Responsibility (1), Pain (1), Traffic accident (1), } \\
\text { Making someone give up (1), Cracked nail } \\
\text { polish (1), Dangerous (1), Nightmare (1), } \\
\text { Boring (1), Handcuffs (1), Slavery (1), Barriers } \\
\text { (1), Referee (1), Germs (1), Method with no } \\
\text { solutions (1), Monster (1), Summer heat (1), } \\
\text { Getting lost (1), Imitation jewelry (1), Captivity } \\
\text { (1), Failure (1), Unnecessary (1), Moving away } \\
\text { from school (1), Difficult to implement (1), } \\
\text { Cooler (1), Silence (1), Demotivating (1), Horror } \\
\text { film (1), Discouraging (1), Whip (1). }\end{array}$ & 40 & 77 & 86 \\
\hline $\begin{array}{l}\text { Punishment as a } \\
\text { positive element }\end{array}$ & $\begin{array}{l}\text { Being motivated (1), Reward (1), Training (1), } \\
\text { Necessary (1), Normal (1). }\end{array}$ & 5 & 5 & 6 \\
\hline No answers & No answers (8). & & 8 & 9 \\
\hline Total & & 45 & 90 & 100 \\
\hline
\end{tabular}

Some of the statements in this category are shown in the following: 


\section{Punishment as a negative element:-}

Metaphors in this category indicate that students perceive punishment in education as negative. Some of the statements in this category are shown in the following:

"Punishment in education is like a bad behavior because punishing students alienates them from a course."

"Punishment in education is like having a vaccination because it hurts."

"Punishment in education is like bitter food because it alienates students from school and from school subjects."

\section{Punishment as a positive element:-}

Metaphors in this category indicate that students perceive punishment in education as positive. Some of the statements in this category are shown in the following:

"Punishment in education is like a reward because it prompts one to find ways not to face the same punishment again."

"Punishment in education is like being motivated because it is the criterion obtained-gained as a result of the wrong behavior."

Table 5:- Findings about the statement "Teachers giving punishment in education are like.... because...."

\begin{tabular}{|c|c|c|c|c|}
\hline Categories & $\begin{array}{l}\text { Teachers giving punishment in education are } \\
\text { like.... because.... }\end{array}$ & $\begin{array}{l}\text { Number } \\
\text { of } \\
\text { metaphors }\end{array}$ & Frequencies & Percentages \\
\hline $\begin{array}{l}\text { Teachers as a } \\
\text { negative element }\end{array}$ & $\begin{array}{l}\text { Having strict attitudes (11), Bad person (11), } \\
\text { Prison officer (3), Soldier (2), Nurse (2), Doctor } \\
\text { (2), Police officer (2), Manager (2), Someone who } \\
\text { is not an educator (2), Incompetent (2), } \\
\text { Frightening (2), Cold (2), Dictator (2), } \\
\text { Unsuccessful (2), Bitter (2), Woodcutter (1), } \\
\text { Dream never coming true (1), Agony (1), Ex- } \\
\text { darling (1), Criminal (1), Failing (1), Unfair (1), } \\
\text { Stick (1), Whip (1), Virus (1), Hangman (1), } \\
\text { Angry (1), Robot (1), A tasteless meal (1), } \\
\text { Pawnbroker (1), Pirate book (1), Queue in a bank } \\
\text { (1), Individual with no communication (1), } \\
\text { Referee (1), Cook (1), Love (1), Watchman (1). }\end{array}$ & 37 & 71 & 74 \\
\hline $\begin{array}{l}\text { Teachers as a } \\
\text { positive element }\end{array}$ & Food (5), Family (4), Educator (4). & 3 & 13 & $\mathbf{1 3 . 5}$ \\
\hline No answers & No answers (12). & & 12 & 12.5 \\
\hline Total & & 40 & 96 & 100 \\
\hline
\end{tabular}

Teachers as a negative element:- Some of the statements in this category are shown in the following:

"Teachers giving punishment in education are like prison officers because they always keep their eyes on you."

"Teachers giving punishment in education are like an ex-darling because you want to get them out of your life."

"Teachers giving punishment in education are like dictators because they oppress others and make them feel bad."

Table 6:-Findings about the statement "Three things punishment in education brings into mind"

\begin{tabular}{|l|c|c|c|c|}
\hline Categories & Three things & $\begin{array}{l}\text { Number } \\
\text { of } \\
\text { metaphors }\end{array}$ & Frequencies & Percentages \\
\hline $\begin{array}{l}\text { Punishment as } \\
\text { a negative }\end{array}$ & $\begin{array}{l}\text { Negative reinforcement (72), Bad behavior (22), } \\
\text { Violence (14), Failure (12), Unhappiness (12), }\end{array}$ & $\mathbf{2 3}$ & $\mathbf{2 2 4}$ & $\mathbf{9 3}$ \\
\hline
\end{tabular}




\begin{tabular}{|c|c|c|c|c|}
\hline element & $\begin{array}{l}\text { Reluctance (11), Getting low marks (10), Fear (7), } \\
\text { Reducing motivation (6), Discipline (6), Learning in } \\
\text { ambition (5), Reduced marks (5), Fear (5), Being } \\
\text { isolated (5), Giving up (4), Having to do (4), } \\
\text { Tension (4), Sadness (4), Not allowing a student to } \\
\text { join classes (4), Sending away (3), Demoralizing } \\
\text { (3), Wrong method (3), Disappointment (3). }\end{array}$ & & & \\
\hline $\begin{array}{l}\text { Punishment as } \\
\text { a positive } \\
\text { element }\end{array}$ & Achievement (2), Cure (1). & 2 & 3 & 1 \\
\hline No answers & No answers (14). & & 14 & 6 \\
\hline Total & & 25 & 241 & 100 \\
\hline
\end{tabular}

\section{Discussion and Conclusion:-}

Students were asked to complete the statement "reward in education is like.... because....", as is seen in Table 1. The students completing the statement divided reward in education into two categories as "reward as an encouraging/illuminating element" and as "reward as a negative element". Accordingly, students perceiving reward in education as an encouraging/illuminating element matched reward mostly with the concepts of reinforcement (17) and food (17). Turhan and Yaras (2013) also found that students perceived reward as reinforcement and that they identified it with such food as chocolate, ice cream, and dessert - which all children love. According to Table 1, it may be said that reward given to students served to make students successful, to make them happy and to motivate them. Rewards give psychological satisfaction and they increase efficiency and motivation (Armstrong \&Murlis, 2004; Wong \& Wong, 2005; Yildirim, 2008).

According to Table 2, students distinguished five categories in relation to "teachers giving rewards in education" namely: "teachers as an encouraging/illuminating element"; "teachers as a need"; "teachers as the owners of power and as the leaders"; "teachers as an emotional expression"; and "teachers as a negative element". On examination of the table of teachers giving rewards in education, we find that those teachers are perceived by students as people who have certain power and who are affectionate. This is a positive perception, and students who accept their teachers with positive properties are expected to display such behaviors as concentrating on those teachers' lessons more, participating more in those classes, and being prepared for exams. Rewards have positive effects on developing teacher-student relations (Jong, Mainhard, Tartwijk, Veldman, Verloop, \&Wubbels, 2014). Besides, receiving a reward results in an increase in an individual's efficiency (Adu, 2015).

As is clear from Table 3, students identify their teachers' words of praise and approval such as "yes", "good", "welldone", and "go on", and food such as candy and chocolate, with the concept of reward as in Table 1. Turhan and Yaras (2013) also found that students associated reward with chocolate, ice cream, candy, and dessert. This indicates that students consider primary and secondary reinforcement most important. In addition to that, elements such as high marks, achievement, motivation, gifts, and encouragement were also found to be connected with reward. Based on the table, it may be stated that receiving a reward triggers such feelings as happiness, ambition, joy, willingness to learn, self-confidence, and excitement in students.

According to Table 4, students divided punishment in education into two categories: as a negative element and as a positive element. The majority of the participants perceived punishment as a bad behavior or as a bad situation. As Dogan, Ugurlu and Karakas (2014) also point out, punishment is a negative element and it has limited and temporary effects. It does not cause the expected effect in changing behavior (Kaya, 2007). Punishment is a pedagogically negative situation which can cause blind obedience and reduction in self-esteem and in selfconfidence, and which intends to eliminate the undesired behavior in a hurtful and unpleasant way (Zakaria, Reupert\& Sharma, 2013). Besides, punishment is also an undesired situation, putting those who give it and those who are exposed to it into a difficult situation, hurting their feelings, and affecting their academic achievement in negative ways (Bulut, 2008; Mahiroglu\&Buluc, 2003). For this reason, punishment should not be employed by teachers who wish to have positive effects on - or to make positive contributions to - their students. Boyaci (2009) also obtained similar results and found that students perceived the concept of punishment as negative. Punishment does not correct undesired behaviors, but it causes the emergence of new problems, the development of negative attitudes, and harm to students. 
According to Table 5, students perceived teachers giving punishment in education as a negative element. Thus, they perceived teachers giving punishment in education as bad people, and they identified them with negative elements. The fact that a teacher gives punishment indicates that he/she is incompetent and weak in practice. It seems impossible for a teacher who is incompetent and weak in the classroom to create a successful classroom atmosphere. A teacher who chooses to give punishment very often in the classroom is highly likely to become a negative figure who students do not like, who students hate, whose classes are not enjoyable, and whose students experience academic failure. In addition to yielding negative results, strict discipline and punishment which is non-proportional to behaviors cause cold and hostile behavior on the part of students towards teachers (Pala, 2005). In conclusion, giving punishment should be avoided when possible for effective and successful learning. Due to the abovementioned reasons, teachers should avoid giving punishment in learning environments.

According to Table 6, students were found to distinguish two categories - namely, punishment as a negative element and punishment as a positive element. Punishment in education contains several negative factors for students. The table also shows the destruction that punishment causes for students. Studies conducted have shown that punishment - and especially physical punishment - can increase aggressiveness, and it can also influence mental health (Gershoff, 2002; Gershoff, 2017; Ghosh\& Banerjee, 2016).

\section{Recommendations:-}

1. Correct and appropriate behaviors displayed by students should be reinforced, but they should not be made addicted to reward.

2. Punishment should be used carefully, since it can cause anger, hatred, and a desire to take revenge on the part of students.

3. Experimental studies demonstrating the ties that reward and punishment have with the brain and nervous system could be performed.

\section{References:-}

1. Abril, C. R., \& Bannerman, J. K. (2015). Perceived factors impacting school music programs: The teacher's perspective. Journal of Research in Music Education, 62(4), 344-361.

2. Adu, E. O. (2015). Institutional, personal and reward system factors as determinants of teachers' productivity in public secondary schools in Oyo State, Nigeria. Journal of Social Sciences (JSS), 45(1), 1-7.

3. Alger, C. L. (2006). Secondary teachers' conceptual metaphors of teaching and learning: Changes over the career span. Teaching and Teacher Education, 25, 743-751.

4. Arik, S., \& Ozdemir, E. B. (2015). Fen ve teknoloji ogretmen adaylarinin fen laboratuarina yonelik metaforik algilari. Kastamonu Egitim Dergisi, 24(2).

5. Armstrong, M., \& Murlis, H. (2004). Reward management: a handbook of remuneration strategy and practice. London: Kogan Page.

6. Arslan, M. M., \& Bayrakci, M. (2006). Metaforik dusunme ve ogrenme yaklasiminin egitim/ogretim acisindan incelenmesi. Milî Egitim, 171, 100-108.

7. Aslan, N. (2016). Teacher images in Spain and Turkey: a cross-cultural study. Asia Pacific Education Review, 17(2), 253-266.

8. Ates, M., \& Karatepe, A. (2013). Universite ogrencilerinin "kuresel isinma" kavramina iliskin algilarinin metaforlar yardımiyla analizi. Marmara Cografya Dergisi, (27).

9. Aydin, A. (2000). Sinif yonetimi. Ankara: Ani Yayincilik.

10. Aydin, B. (2006). Ogretmenlerin kendi sinif disiplin sistemlerini olusturmasi. Sosyal Bilimler Arastirmalari Dergisi, 19 (2), 19-32.

11. Aydin, F. V., \& Unaldi, U. E. (2010). Cografya ogretmen adaylarinin "Cografya” kavramina iliskin algilarinin metaforlar yardimiyla analizi. International Online Journal of Educational Sciences, 2(2), 600-622.

12. Aydin, I. S., \& Pehlivan, A. (2010). Turkce ogretmeni adaylarinin "ogretmen" ve "ogrenci" kavramlarina iliskin kullandiklari metaforlar. Turkish Studies, 5(3), 818-842.

13. Boyaci, A. (2009). Ilkogretim ogrencilerinin disipline sinif kurallarina ve cezalara iliskin goruslerinin karsilastirmali olarak incelenmesi (Turkiye-Norvec ornegi). Kuram ve Uygulamada Egitim Yonetimi, 60(60), 523-554.

14. Bulut, S.(2008). Okullarda gorulen ogrenciden ogrenciye yonelik siddet olaylarinin bazi degiskenler acisindan arsiv arastirmasi yontemiyle incelenmesi. Abant Izzet Baysal Universitesi, Egitim Fakultesi Dergisi, 8(2), 2338. 
15. Calik, O. (2016). Cizvit Egitiminde Odul ve Ceza. Ignatius Loyola ve Cizvit Okullarinin, 53.

16. Charteris-Black, J. (2004). Corpus approaches to critical metaphor analysis. Hampshire/New York: Palgrave Macmillan.

17. Dogan, S., Ugurlu, C. T., \& Karaka, H. (2014). Etkili sinif yonetimi uygulamalarina iliskin ogretmen goruslerinin degerlendirilmesi. Gaziantep University Journal of Social Sciences, 13(4), 1097-1119.

18. Dokmen, U. (2005). Kucuk seyler. Istanbul: Sistem Yayincilik.

19. Eren, F., Celik, I., \& Akturk, A. O. (2014). Ortaokul ogrencilerinin facebook algisi: bir metafor analizi. Kastamonu Egitim Dergisi, 22(2), 635-648.

20. Ekiz, D., \& Kocyigit, Z. (2013). Sinif ogretmenlerinin “ogretmen” kavramina iliskin metaforlarinin tespit edilmesi. Kastamonu Egitim Dergisi, 21(2), 439-458.

21. Gamlem, S. M., \& Smith, K. (2013). Student perceptions of classroom feedback. Assessment in Education: Principles, Policy \& Practice, 20(2), 150-169.

22. Gershoff, E. T. (2002). Corporal punishment by parents and associated child behaviours and experiences: A meta-analytic and theoretical review. Psychological Bulletin, 128 (4), 539.

23. Gershoff, E. T. (2017). School corporal punishment in global perspective: prevalence, outcomes, and efforts at intervention. Psychology, Health \& Medicine, 22: sup1, 224-239.

24. Ghosh, P. D., \& Banerjee, M. (2016). Does subjective well-being depend on childhood punishment? An exploratory study. The International Journal of Indian Psychology, 4 (1), 132-140.

25. Gocer, A. (2013). Turkce ogretmeni adaylarinin dil kultur iliskisi uzerine gorusleri: fenomonolojik bir arastirma. Erzincan Universitesi Egitim Fakultesi Dergisi, 15(2), 25-38.

26. Hoffman, L., Hutchinson, J., \& Reiss, E. (2009). On improving scholl climate: Reducing reliance on rewards and punihments. International Journal of Whole Schooling, 5(1), 13-24.

27. Ibret, B. U., \& Aydinozu, D. (2011). Ilkogretim II. kademe ogrencilerinin "Dunya" kavramina iliskin gelistirdikleri metaforlar. Kastamonu Egitim Dergisi, 19(1), 85-102.

28. Jong, R., Mainhard, T., Tartwijk, J., Veldman, I., Verloop, N., \& Wubbels, T. (2014). How preservice teachers' personality traits, self efficacy, and discipline strategies contribute to the teacher-student relationship. British Journal of Educational Psychology, 84(2), 294-310.

29. Kaya, A. (2007). Edimsel (Operant) kosullanma. Ankara: Pegema Yayincilik.

30. Kaya, M. F. (2014). Sosyal bilgiler ogretmen adaylarinin cevre sorunlarina iliskin algilari: metafor analizi ornegi. Turkish Studies-International Periodical For The Languages, Literature and History of Turkish or Turkic, Volume 9/2 Winter 2014, 917-931.

31. Koc, M. (2013). Student teachers' conceptions of technology: A metaphor analysis. Computers \& Education, $68,1-8$.

32. Lakoff, G., \& Johnson, M. (2005). Metaforlar hayat, anlam ve dil, (Cev: Demir, G.Y.). Istanbul: Paradigma Yayincilik.

33. Leavy, A.M., Mcsorley, F.A., \& Bote, L.A. (2007). An examination of what metaphor construction reveals about the evolution of preservice teachers' beliefs about teaching and learning. Teaching and Teacher Education, 23, 1217-1233.

34. Mahiroglu, A., \& Buluc, B. (2003). Orta ogretim kurumlarinda fiziksel ceza uygulamalari. Turk Egitim Bilimleri Dergisi, 1(1).

35. Martinez, M.A, Sauleda, N., \& Huber, G.L. (2001). Metaphors as blueprints of thinkking about teaching and learning. Teaching and Teacher Education, 17, 965-977.

36. Moser, K. S. (2000). Metaphor analysis in psychology-Method, theory, and fields of application. In Forum Qualitative Sozialforschung/Forum: Qualitative Social Research, (Vol. 1, No. 2).

37. Navaro, L. (2009). Gercekten beni duyuyor musunuz? Istanbul: Remzi.

38. Nikitina, L., \& Furuoka, F. (2011). Revisiting metaphors for education: a student's perspective. Asia Pacific Education Review, 12(2), 311-318.

39. Nuttin, J., \& Greenwald, A. G. (2014). Reward and punishment in human learning: Elements of a behavior theory. New York and London: Academic Press.

40. Ozdemir, M. (2010). Nitel veri analizi: Sosyal bilimlerde yontembilim sorunsali uzerine bir calisma. Eskisehir Osmangazi Universitesi Sosyal Bilimler Dergisi, 11(1).

41. Pala, A. (2005). Sinifta istenmeyen ogrenci davranislarini onlemeye donuk disiplin modelleri. Manas Universitesi Sosyal Bilimler Dergisi, 13, 171-179.

42. Roache, J., \& Lewis, R. (2011). Teachers' views on the impact of classroom management on student responsibility. Australian Journal of Education, 55(2), 132-146. 
43. Romi, S., \& Roache, J. (2012). Excluding students from classroom: Teacher techniques that promote student responsibility. Teaching and Teacher Education, 28(6), 870-878.

44. Saban, A., Kocbeker, B. N., \& Saban, A. (2006). An investigation of the concept of teacher among prospective teachers through metaphor analysis. Kuram ve Uygulamada Egitim Bilimleri, 6(2), 461-522.

45. Saban, A. (2008). Giris duzeyindeki sinif ogretmeni adaylarinin "ogretmen" kavramina iliskin ileri surdukleri metaforlar. Turk Egitim Bilimleri Dergisi, 2(2), 131-155.

46. Saban, A. (2009). "Ogretmen adaylarinin ogrenci kavramina iliskin sahip oldugu zihinsel imgeler". Turk Egitim Bilimleri Dergisi, 7(2), 281-326.

47. Swanson, L. R. (2001). Toward the ethical motivation of learning. Education, 116(1), 43-50.

48. Tannehill, D., \& MacPhail, A. (2014). What examining teaching metaphors tells us about pre-service teachers' developing beliefs about teaching and learning. Physical Education and Sport Pedagogy, 19(2), 149-163.

49. Turhan, M., \& Yaras, Z. (2013). Ogretmen ve ogrencilerin ogretmen, disiplin, mudur, sinif kurallari, odul ve ceza kavramlarina iliskin metafor algilari. Firat Universitesi Sosyal Bilimler Dergisi, 23(1), 129-145.

50. Vadeboncoeur, J. A., \& Torres, M. N. (2003). Constructing and reconstructing teaching roles: a focus on generative metaphors and dichotomies. Discourse: Studies in the Cultural Politics of Education, 24(1), 87-103.

51. Vosniadou, S. (1989). Context and the development of metaphor comprehension. Metaphor and Symbol, 4(3), 159-171.

52. Wahyudi, W. (2007). Using metaphors to explore teachers' perceptions of school science curriculum: an Indonesian lower secondary schools case. In Second International Conference on Science and Mathematics Education, Penang, Malaysia(Vol. 17, p. 2011).

53. Wong, P.M., \& Wong, C.S. (2005). Promotion criteria and satisfaction of school. Educational Managment Administration Leadership, 33(4), 423-447.

54. Yaman, E., \& Guven, N. (2014). An important concept affecting students' motivation levels: Rewards and punishments Ogrencilerin motivasyon duzeyine etki eden onemli bir kavram: Odul ve ceza. Journal of Human Sciences, 11(1), 1163-1177.

55. Yildirim, C. M. (2008). Ilkogretim okulu ogretmen ve yoneticilerinin ogretmenlerin odullendirilmesine iliskin gorusleri. Kuram ve Uygulamada Egitim Yonetimi Dergisi, 14(4), 663-690.

56. Yilmaz, F., \& Babaoglan, E. (2013). Reward and punishment methods used elementary teachers to provide classroom discipline. Elementary Education Online, 12(1), 36-51.

57. Zakaria, N., Reupert, A., \& Sharma, U. (2013). Malaysian primary pre-service teachers' perceptions of students' disruptive behaviour. Asia Pacific Education Review, 14(3), 371-380. 